\title{
Conceptualizing Model of Factors Influencing Electronic Commerce Adoption in Iranian Family SMEs
}

\author{
Seyed Kaveh Jamali ${ }^{1}$, Govindan Marthandan ${ }^{1}$, Mahdi Khazaei ${ }^{2}$, Behrang Samadi ${ }^{3}$ \& David Yong Gun Fie ${ }^{4}$ \\ ${ }^{1}$ Graduate School of Management, Multimedia University (MMU), Malaysia \\ ${ }^{2}$ Faculty of Economics and Social Sciences, Bu-Ali Sina University, Iran \\ ${ }^{3}$ Faculty of Business and Management, Asia Pacific University of Technology and Innovation (A.P.U), Malaysia \\ ${ }^{4}$ Faculty of Management, Multimedia University (MMU), Malaysia \\ Correspondence: Seyed Kaveh Jamali, Graduate School of Management, Multimedia University (MMU), \\ Malaysia. E-mail: jamali.kaveh@yahoo.com
}

Received: November 22, 2014 Accepted: January 20, 2015 Online Published: April 20, 2015

doi:10.5539/ass.v11n10p256 URL: http://dx.doi.org/10.5539/ass.v11n10p256

\begin{abstract}
Purpose - This paper aims to provide a conceptual model for the purpose of examining potential influencing factors as well as particular effect of family SMEs' heterogeneity factors on EC adoption in Iranian family SMEs.

Design/methodology/approach - The conceptual model originates from EC adoption study backgrounds, grounded in the major concepts of frequently EC adoption and their dependent-extended models. Literature review presents relevant items under their main first order factors, including family SMEs' heterogeneity factors, categorized by contexts.

Findings - The model, in which EC adoption refers to the significance of 'Extent of Deployment' as innovation behavior, respecting to the theoretical basis of human behavior including essential pure theories (i.e. Learning; Anchoring-and-Adjustment) and major concepts of frequently EC adoption models (TAM; TPB; SCT; DOI), besides role of family SMEs' heterogeneity factors (i.e. The moderating effects of 'Family Strategic Orientation') provided a basis for assessing potential EC adoption antecedents (under which different facets of EC adoption would be considered) including $13^{\text {th }}$ first orders, categorized under four main individual, organizational, industrial, and national contexts.

Practical implications - As a sustainable business market mean, EC adoption as an extra-exploitation of electronic commerce, making wider and more diversified external 'business-linked' and/or 'customer-linked' business relationships, particularly for family SMEs that suffer from 'marketing deficiency', time and effort is necessary so as to identify influencing factors and diagnose their effects on EC deployment in such Iranian SMEs, where EC adoption is questionably near to ground. The presented model is quite valuable for the analysis.

Originality/value - This paper presents a conceptual model for analyzing EC adaption factors under related contexts. Independent influences of 12 first potential factors categorized in four contexts as well as the moderation effect of 'family strategic orientation' variable on EC adoption are studied in the model. The design differs from previous studies as they used dichotomous approaches for 'family strategic Orientation' determination.
\end{abstract}

Keywords: electronic commerce, EC adoption, family SMEs, Iranian family SMEs, family (strategic) orientation, intergenerational succession

\section{Introduction}

Family SMEs as the majority of family businesses, which in turn are the most spread businesses across the world (Astrachan \& Torsten, 2010), play an important role in the global economy, by creating a safe and transparent investment environment, overcoming the milieu of economic crisis. Family SMEs are the crucial section, not merely based on their critical involvement in economy, but presenting a long-term steadiness and responsibility. They represent $70-90 \%$ of the global GDP (Wealth and the Barclays Economist Intelligence Unit, 2009), 50\% of the GDP and employment in US (Astrachan \& Jaskiewicz, 2008), more than $60 \%$ of the European companies in a vast range of sectors (European commission reports, 2009), two-thirds of Small and Medium Enterprises (SMEs) as the dominant form of business in Australia (Kotey, 2005), more than $90 \%$ of Japanese domestic companies 
(Astrachan \& Jaskiewicz, 2008), 95\% of the private companies in the Middle East (Walton and Whitener, 2010) and dominate form of SMEs compromising 98\% of business in Iran (Jamali et al., 2015). Relatively, the regional advancement in the majority of societies are highly depends on the family SMEs' contribution (IFERA, 2003). They have a direct effect on poverty reduction and employment by sharing the economic pie to the societies' disadvantageous like youngsters and absorbing the redundant manpower, resulting from governments' privatization policies. However, despite the numerous advantages, they evidently suffer from serious challenges such as limited resources, deficiency of internationalization and unknown image. Accordingly, they need to develop their internationalization strategy, resourcing and business image (Lohrke et al., 2006).

In the new-industrial growth paradigm, the need for growth and sustained competitiveness are more particularly perceived by family SMEs (Gersick et al., 1997). relatively, the electronic commerce could be a critical investment, not only as a competitive driver, but also as an integral part of the strategic business plan with direct business-concerned benefit points (i.e. in-house efficiency enhancement and operational savings) and indirect business-concerned benefit points (i.e. internationalization and market position improvement) (Iacovou, Benbasat, $\&$ Dexter, 1995). It could help them overcoming their existing challenges, and guaranteeing their long term way of life by side to side superior economy of scale and resource accessibility. However, family SMEs express an idiosyncratic feature, in which the organizational need is perceived under lens of three intertwined family, business and CEO concerns (Sharma, Chrisman, \& Chua, 1996). Accordingly, their perception of innovation characteristics and advantages not only should fulfill their business-related needs such as changes, growth and internationalization, but also should satisfy the family-related and CEOs'-related needs.

There is a considerable question as whether electronic commerce practices can be adopted in a same approach in businesses. While EC adoption is broadly considered by large companies from corner to corner in the world, adoption of EC in the SMEs is lagging behind (Lee \& Xia, 2006). It seems large-sized companies and SMEs, according to their nature and technological needs, act differently in electronic commerce adoption. Although various challenges in concern with EC adoption in SMEs are also concerned in family SMEs in general, but some challenges are exclusive to family SMEs. As aforementioned, the unbalanced priorities in family, CEO and business subsystems in family firms might be a clue to better understanding of the differences. The family and CEO concept and their effects on family SMEs' behavior are the primary entrance way to distinguish family SMEs from Non-family SMEs in terms of EC adoption. Family SMEs, compared with the Non-family SMEs, operate under dissimilar limitations and diverse objectives. They have distinctive needs for tracking the Non-commercial objectives; thus, are managed differently (Leach et al., 1990; Leach, 1994). Moreover, they suffer from a lack of attractiveness to absorb skilled workforce, due to their sense of nepotism (KMU Forschung Austria, 2008). There are considerable challenges between following the profit or Non-commercial goals in family SMEs, depending on their strategic orientation (Sharma et al., 1997), so-called 'Family (Strategic) Orientation'. Unlike Non-family SMEs, the direct benefits of EC in family SMEs may be perceived as less tangible, compared to the EC indirect benefits (KMU Forschung Austria, 2008). Moreover, family SMEs are more conservative, regarding to their long term family control and ownership desiring (Donckels \& Frohlich, 1991), which may disarm them from typical SMEs' innovativeness and flexibility. There are also some other differences related to how they interact with the environmental context, such as interactions with social environment and government that may alter their approach to EC adoption. For instance, family SMEs; unlike Non-family SMEs, have an intense networking interest to the social and not to the economic business partners (KMU Forschung Austria, 2008). Moreover, the existing studies indicated that, there is a clear lack in terms of EC adoption in developing countries, which hold them behind of development countries in this respect (Kartiwi, 2006). This is particularly more considerable, as far as the SMEs in such countries are concerned (Sam \& Leng, 2006). Such paucity in terms of EC adoption in developing countries implies that the EC adoption factors in SMEs might be variations in the different nations, regarding to the socioeconomic differences such as infrastructural and cultural aspects (Daniel \& Grimshaw, 2002; Sarosa \& Underwood, 2005; Kartiwi \& MacGregor, 2007).

Despite the considerable body of EC adoption literature in LSEs and SMEs' domains, there is still a little known about EC adoption in family SMEs' context, particularly in developing countries. Likewise, the majority of EC adoption study in Iran (as a developing country) has been performed in the LSEs and SMEs and there is almost no exclusive study on family SMEs. On the other hand, regarding to the significant differences among EC adoption studies in developing and developed countries; LSEs and SMEs; and particularly Non-family SMEs and family SMEs (with respect to the unique family SMEs' attributes; such as, altruism, conservatism, independency and social networking), the generalization of the previous results of related studies into Iranian family SMEs is questionable. Accordingly, we were motivated by a concern that the low rate of average EC adoption in Iranian family SMEs could be impacted by the particular factors in such distinct SMEs in Iran regarding to their unique 
cultural, legal, infrastructural, economic, and even political situation. Thus, gaining knowledge about the CEO as a dominant decision maker in family SMEs in Iran and their perceptions of the potential related factors was vital in order to extend the EC deployment among Iranian family SMEs. As such, this study examined the past literature and then supplemented this work by examining the relationship between each first order antecedents and EC adoption.

The rest of this paper is structured as follows: most frequently used EC adoption models in a broader domain of SMEs' literature are studied in the Literature review section. Then, in the following section, the potential influencing factors on EC adoption in Iranian family SMEs are identified and respective propositions are made. Next, the development of the conceptual research framework is described. Then, both theoretical and managerial implications as well as avenues for further research are presented. Finally, conclusions are drawn with respect to the new knowledge derived from this research study.

\section{Literature Review and Propositions Development}

In the literature the majority of existing EC adoption studies have been investigated in the LSEs and/or SMEs, and there is an evident gap in related studies in family SMEs' context, especially in the developing countries. The number of articles, journals and general studies in family SMEs' context, compared to the overall studies, is considerably low (Astrachan \& Torsten, 2010), which it seems to be even worse in case of developing countries (Gomez, 2012). Shanker and Astrachan (1996) underlined two main reasons in this respect: a) family SMEs have not been considered as a distinct entity for a long time by government agencies and even academics, b) There is almost no specific definition for family SMEs; thus, conducting research in such businesses is difficult. Relatively, there is almost not a quite understanding of the ways that family SMEs venture new technologies, operate, and source their needs in the market.

Table1. EC adoption studies with additional factors and/or models in SMEs' context

\begin{tabular}{|c|c|c|}
\hline Study & $\begin{array}{l}\text { Theoretical } \\
\text { Basis }\end{array}$ & Additional Factors \\
\hline Iacovou et al. (1995) & DOI & External pressure, organizational readiness \\
\hline $\begin{array}{l}\text { Premkumar and Roberts } \\
\text { (1999) }\end{array}$ & DOI & Top management support, Firm Size External pressure \\
\hline Chwelos et al. (2001) & DOI & External pressure, Organizational readiness \\
\hline Kuan and Chau (2001) & DOI & Organizational Factors, Environmental Factors \\
\hline Mehrtens et al. (2001) & DOI & $\begin{array}{l}\text { Organizational readiness } \\
\text { - External pressure }\end{array}$ \\
\hline $\begin{array}{l}\text { Mirchandani and Motwani } \\
(2001)\end{array}$ & DOI & $\begin{array}{l}\text { - Management time, Employees' computer knowledge, } \\
\text { Information intensity, competition, cost }\end{array}$ \\
\hline $\begin{array}{l}\text { Lertwongstien and } \\
\text { Wongpimmwatana (2003) }\end{array}$ & DOI & Organizational Factors, Environmental Factors \\
\hline Al-Qirim (2007) & DOI & $\begin{array}{l}\text { Cost, Size, Information intensity, Vendor support, External } \\
\text { pressure, CEO's Innovativeness and Involvement }\end{array}$ \\
\hline Jeon et al. (2006) & DOI & $\begin{array}{l}\text { Management characteristics, Organizational characteristics, } \\
\text { Environmental characteristics, } \\
\text { Business strategic orientation }\end{array}$ \\
\hline Lee $(2004)$ & DOI, SCT & Competitive Pressure, Financial slacks, Innovativeness \\
\hline Seyal et al. (2004) & DOI, TAM & Organizational Factors, Environmental Factors \\
\hline Wymer and Regan (2005) & $\begin{array}{l}\text { DOI, TAM, } \\
\text { TPB, SCT }\end{array}$ & ------------- \\
\hline Grandon and Pearson (2004) & TAM & $\begin{array}{l}\text { Organizational readiness, External pressure, Compatibility, } \\
\text { Organizational support }\end{array}$ \\
\hline Dholakia and Kshetri (2004) & $\mathrm{SCT}$ & $\begin{array}{l}\text { Firm Size, Prior technology use, Prior media use, Perceived } \\
\text { Competitive Pressure }\end{array}$ \\
\hline Kula and Tatoglu (2003) & TPB & Attitude toward Internet use \\
\hline Celuch et al. (2007) & TPB, SCT & 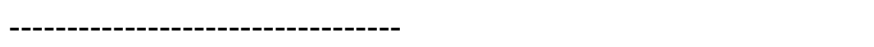 \\
\hline
\end{tabular}


Despite the noticeable efforts clarifying EC adoption phenomenon in Iranian SMEs (i.e., Ghamatrasa, 2006; Ajdari, 2007; Afzal, 2008; Hajkarimi \& Azizi, 2008; Sanayei \& Rajabion, 2009; Ghorishi, 2009; Sameni \& Khoshalhan, 2009; Abbasi, Sarlak, Ghorbani, \& Esfehani, 2010; Ghobakhloo, Aranda, \& Amando, 2011a; Ghobakhloo, Aranda, \& Amando, 2011b; Hajli \& Bugshan, 2012); there is almost no related study in family SMEs' context in Iran. Furthermore, the significant differences in terms of EC adoption, between large-sized and SMEs, Non-family SMEs and family SMEs, and also developing and developed countries had made the usage of existing SMEs' EC adoption models and findings not quite appropriate to explain EC adoption in family SMEs.

In the SMEs' literature, the following models have been widely approached: Diffusion of Innovation Model (DOI) (Rogers, 1983, 1995, 2003); Social cognitive theory (SCT) (Bandura, 1986); Theory of Planned Behavior (TPB) (Ajzen, 1991); Technology Acceptance Model (TAM) and their dependent extensions models: TAM1 (Davis, 1989), TAM2 (Venkatesh \& Davis, 2000) and UTAUT (Venkatesh, Morris, Davis, \& Davis, 2003). However, as aforementioned, these model do not seem to be multi-faceted models for explanation of EC adoption in family SMEs' and even in general SMEs' context, as they are often considered with some additional factor(s)/model(s) for better clarification of EC phenomenon in such businesses, in the related literature (See Table 1).

The current study aims to present a rather comprehensive EC adoption framework in Iranian family SMEs' context; by contextually extracting the main concepts of the most frequently used EC adoption models in the related literature (DOI, SCT, TAM, TPB), and then fulfilling their limitation by applying the additional related factors studied in the literature and/or suggested by the current study by using of the literature. As aforementioned, the existing related models had some limitation points accounting for explaining 'EC Adoption' in SME, and family SMEs in particular. The core concentration of the existing models accounting for EC adoption had focused on the 'Individual' and 'Technological' contexts.

To better explain the EC adoption phenomenon in the related contexts, a considerable range of additional factors had been applied in the literature to represent the 'Organizational' and 'Environmental' aspects, proving the point that for presenting an EC adoption comprehensive framework in such businesses there is a need to embrace other relevant factors. In this respect, in order to overcome the aforementioned restrictions, Tornatzky and Klein (1982) applied the widely relevant additional factors that influence the deployment of an innovation, by indicating ten regularly used factors in the related literature, from 75 innovation researches. Accordingly, they presented a three-context framework, called Technology- Organization- Environment (TOE), which consequently had often applied for explaining EC adoption in SMEs, and family SMEs (i.e. Wang \& Ahmed, 2009) in the literature. Carayannis and Turner (2006), and Jeon et al. (2006) showed the constant relationship between TOE framework and the 'Adoption behavior'. However, since the factors related to the 'Individual' context (i.e. Subjective Norm; Attitude; Perceived Behavioral Control) were not concerned in the TOE framework, it could not be as a multi-faceted framework explaining EC adoption in family SMEs, where an individual owner-manager CEO is a dominant decision maker.

Considering the restriction, Thong (1999) compounded the 'Individual' context to the TOE, presenting the four major contexts; Management (Individual), Technological, Organizational, and Environmental. However, even after such modifications in the model by Thong (1999), it still overlooked the 'Industrial' context or overlapped that with 'Environmental' context (Looi, 2005). More Recently, Alzougool and Kurnia (2008) presented a rather complete framework explaining EC adoption in such businesses involving 'Organizational', 'Industrial', 'National' and 'Environmental' (readiness) contexts. In this model, the 'National' context is credited to perceived availability of agencies' supports and national structure in relation to 'EC Adoption'. The 'Organizational' context was referred to the perceptions of top managers from the resources, regulations, procedures and processes in the organization in relation to 'EC Adoption'. The 'Industrial' context indicated the perceptions of top managers from the standards and business partners' readiness in the industry in relation to the 'EC Adoption'. And, the 'Environmental' context was referred to the conforming perceived internal and external expectation/pressures in EC adoption. The latter model almost covered down the limitation of previous frameworks, by considering the related factors in the missing 'Industrial' context, as meso level, between 'Organizational' (micro level) and 'National' (macro level) contexts; however, it overlooked the 'Individual' context or overlapped that with the 'Organizational' context.

In the current study, the three contexts of Alzougool and Kurnia's (2008) framework, involving 'Organizational', 'Industrial' and 'National' readiness, were realized as a constructive model, covering most of the contextual restrictions of frequently used models in the literature. In addition, the 'Individual' context, with a wider concept of the 'Management' context (Thong, 1999), involving the individual factors which elevate the readiness (Intention) to obtain the given behavior was applied in this study. 
The 'Individual' (readiness) context in this research encompassed the individual factors as well as the 'Perceived Usefulness', because the electronic commerce awards are not integral to the innovation as such but are related to how are perceived by a CEO as the dominant decision maker in such businesses. 'Perceived Usefulness' was previously grouped under the 'Technological' Context (e.g., Tornatzky \& Fleischer, 1990) and/or in 'Organizational' context (e.g., Gibbs \& Kraemer, 2004; Alzougool \& Kurnia, 2008) in the literature. Moreover, based on the study of Wu and Wang (2005), the 'Environmental pressures' as the forth context of model in the study of Alzougool and Kurnia (2008), which is referred to the perceived internal and external pressures (expectation) by CEO to comply with the electronic commerce adoption, was represented by 'Subjective Norm' as the CEO's perception of people who are important to him/her think he/she should or should not perform the behavior and grouped under the 'Individual' (readiness) context. Additionally, the concept of environmental effects and their related factors in the literature were grouped under 'National (readiness) context in the current study. As a result, in this research the related factors were categorized under four-context EC adoption framework, involving 'Individual', 'Organizational', 'Industrial' and 'National' (readiness) contexts.

The four main contexts undertook the related factors as a result of joining the most used theoretical models in SMEs and the relevant additional factors studied in the prior SMEs and family SMEs literature and/or extracted from the exclusive family SMEs' literature based on the similarities. The boldface factors in the table were studied in the SMEs in developed countries which have not been investigated in the developing countries. The highlighted factors were studied in the particular family SMEs' context. The Italic factors were studied in the SMEs in Iran. The underlined factors were used in the four main theoretical SMEs' EC adoption models; TAM, TPB, SCT, DOI, and/or their dependent-extension efforts UTAUT, TAM2 (See Appendix A).

\section{Relationship between Potential Influencing Factors and EC Adoption}

Table 2. First order and their related aspect items suggested by the current study

\begin{tabular}{l} 
First Order Factor \\
EC Adoption \\
\hline 1) Perceived (EC) Need \\
2) Perceived \\
Usefulness (Awards) \\
3) Perceived disadvantages \\
(Risk)
\end{tabular}

4) Subjective Norm

5) Anchor

6) Adjustment

7) Intergenerational

Successions

8) Perceived Organizational Resources

9) Perceived Organizational Governance

10) Perceived Organizational Support

11) Perceived Industry Structure Structure Orientation
12) Perceived National

13) Family

Aspect items
EC Volume, EC Diversity, EC Breadth

Perceived Need for: Being on the Field, Business Image, Family Image, Growth and Internationalization, Managerial Control

Perceived Business Advantages, Perceived Family Advantages, Perceived CEO's Advantages, Perceived Observability, Perceived Compatibility, Perceived Trialability, Perceived Reliability

Perceived Security Issues, Perceived External Business Risks, Perceived Dissipating Company-Specific Knowledge, Perceived Organizational Dependency

Perceived Government Pressure, Perceived Passion for Business Excellence, Perceived Customers/Buyers Pressure, Perceived Family's Social Network Interest, Perceived Pressure for Cherish Family Wealth, Perceived Suppliers Pressure (Khoje et al., 2013)

CEO's Attitude (toward EC), Perceived Behavioral Control , CEO Interests , CEO's Innovativeness, CEO's Risk Taking, CEO's EC Related Knowledge and Experience

Perceived (EC) Business Performance Satisfaction, Perceived (EC) Family Performance Satisfaction, Feedback Effects of Adoption Decision

Managerial Successions, Ownership Successions, Generational Non-Involvement

Perceived Financial Resources, Perceived Skilled Human Resources, Perceived Informational Resources, Organizational Awareness, Managerial Time

Organizational Policy and Institutional Framework, Communication Channels, Communication Amount, Having Systematic Process for Managing Change Issues, Having Clearly Defined Roles

Perceived Family Support, CEO Practical (Involvement) Support Perceived Active (Supportive) Directors' Board, Perceived Employees (Involvement) Support

Perceived Availability of: Standards, Information Intensity and Product Characteristics, Online Resources, Portal and Databases, Models of Successful Use, Communicative and Trusted Trading Partners, Coordinating Bodies, Perceived Competition Amongst

Perceived Availability of: Telecommunication Infrastructure, Logistics and Transport Infrastructure, EC Adopted Banking System, EC-Related Technology Vendors, Regulatory and Legal Environment and Support, Perceived Public Awareness, Perceived Public Purchasing Behavior (Culture), External Expertise and Services Availability and Support, Perceived Government Support and Commitment

Note: Highlight-factors have not been pointed out in the previous related studies 
First order factors (12 independent and 1 moderating factor), categorized under four main 'Individual', 'Organizational', 'Industrial', and 'National' contexts (See Appendix A) were underlined as potential EC adoption factors in Iranian family SMEs by the current study. A definition of the selected factors and 'EC adoption' were relatively detailed (See Appendix B). Then, through a comprehensive literature review, their aspect items were pointed out, as follow (See Table 2).

\subsection{Perceived Need}

According to Hersey and Blanchard (1993), perceived need as CEO's perception of inner motives may cause a motivational situation directed to the balancing inner actual states and desired states by taking a behavior toward given goal. Accordingly, the common thread of better understanding of the family SMEs' behavior might be found at the perception of CEOs from the 'Need', concerning with the three main subsystems of family, business and CEOs in such SMEs. CEO's perception of E-commerce characteristics and advantages, not only should be perceived as their business-related need, but also should be perceived as family-related and/or CEO-related needs. This might be a clue for better understanding of actual scarcity toward EC in such SMEs, while EC adoption through accessing the potential worldwide market without time and space limitations, seems to be a demanding solution. Perceived need, as a main behavioral motive, had not received enough attention in the related literature and also the research findings in SMEs might not be quiet appropriate to be applicable in family SMEs; therefore, the following proposition is presented:

$P 1$. Perceived need has a direct effect on EC adoption in Iranian family SMEs.

\subsection{Perceived Usefulness (Awards)}

Perceived usefulness is not integral in technology per se; but, it refers to how it is perceived by the CEO. It is defined as the extent to which a CEO believes that the applications of the EC would make her/him able to do the tasks better (Davis, 1989). Prior studies evidenced that EC usefulness plays a significant role in EC adoption (Riemenschneider et al., 2003; Lin \& Wu, 2004; Grandon \& Pearson, 2004; Roberts \& Toleman, 2007). Effect of perceived usefulness on EC adoption was significantly approved in SMEs' context in Iran (Ghamatrasa, 2006; Ghorishi, 2009; Abbasi et al., 2010; Hajiha et al., 2010). However, in the family SMEs, EC usefulness is perceived through the lens of three intertwined family, CEO and business subsystems. Accordingly, the EC usefulness in such distinct SMEs not only should fulfill their business needs, such as change, growth and internationalization, but also should satisfy family needs; such as family's image besides CEO needs, respect to his/her managerial control. As perceived usefulness seemed to be a critical factor in EC adoption behavior in SMEs; the following proposition is presented:

$P 2$. Perceived usefulness (awards) has a direct effect on EC adoption in Iranian family SMEs.

\subsection{Perceived (EC) Disadvantages}

In spite of the importance of lose side in decision makings, as explained by prospect theory (Tversky \& Kahneman, 1991), the perceived EC disadvantages (risks), defined as the CEO's perception of to what extent they have incurred a loss by using any on-line service (extracted from Lim, 2003), as the lose side of EC adoption decision, have not received enough attention in the related literature. Alzougool and Kurnia (2008) highlighted the significant role of perceived (EC) disadvantages (risks) on EC adoption. This factor was moreover addressed as a determinant factor in EC adoption of Iranian SMEs (Hajkarimi \& Azizi, 2008). The perceived (EC) disadvantages in the family SMEs, where there is a "large undiversified asset linked to the ownership, "endowment attachment" and "ineffective separation between business and personal asset" (Welsh \& Zellweger, 2010) is even more considerable for EC adoption in compare with non-family SMEs. Therefore the following proposition is presented:

P3. Perceived disadvantages (risks) has a direct effect on EC adoption in Iranian family SMEs.

\subsection{Subjective Norm}

Subjective norm is defined as CEO's perception that most people who are important to him/her think he/she should or should not perform the behavior in question (Fishbein \& Ajzen, 1975). The role of subjective norm had been evidently studied by prior researches in SME domain (e.g., Kula \& Tatoglu, 2003; Riemenschneider et al., 2003; Sarosa \& Underwood, 2005; Dawkins \& Frass, 2005; Ghamatrasa, 2006; Celuch et al., 2007; Nasco et al., 2008; Abbasi et al., 2010; Hajiha, et al., 2010). However, regarding to the significant differences in case of CEO's perception of internal and/or external expectation (pressure) in family SMEs caused by their unique characteristics, such as networking intensity, dependency, conservativeness and altruism, the role of subjective norm in such district SMEs, as recently considered by a study of Niehm et al. (2010) needs more investigation. Therefore, the following proposition is presented: 
P4. Subjective norm has a direct effect on EC adoption in Iranian family SMEs.

\subsection{Anchor}

Based on the anchoring and adjustment theory, the theme of 'Anchor' represents a broader concept of (initial) self-evaluation of result desirability. It is defined as the individual initial evaluation of results' desirability. The long life-run experiences as a base of individual initial evaluation was supported by decision theory explaining that the 'Expected Results' is intuitively perceived by the law of large numbers of experiences. Self-perception of behavioral, and control beliefs toward a given behavior, forming the individuals' perception of the possibility that efforts will be led to the desired outcomes, corresponded with 'Perceived Desirability' of results, and 'Perceived Feasibility' of attainment toward given innovation behavior in the innovation adoption literature (e.g. Krueger, Reilly and Carsrud, 2000). The concept of 'Anchor' and its influence on the actual behavior was supported by Venkatesh and Bala (2008). In the typical family SMEs, an owner-manager CEO is dominantly responsible for driving the decision in organization. So, their (initial) self-evaluation of EC result desirability was assumed as a potential EC adoption predictor. Therefore, the following proposition is presented:

$P 5$. Anchor has a direct effect on EC adoption in Iranian family SMEs.

\subsection{Adjustment}

The behavior of a CEO in an organization is not by random. A behavior is an action, aimed to achieve satisfaction. Based on the anchoring and adjustment theory, to represent the concept of adjusted process-run-time evaluation of satisfaction, the theme of 'Adjustment' is applied. Adjustment is defined as the "Performance-based individual adjustment in mental evaluation of satisfaction". In the current study, the 'Adjustment' is determined by 'Perceived Enjoyment', 'Feedback Effects of Adoption Decision' (as an initial adjustment) and 'Performance Satisfaction' (refer to its instrumentality as accomplishment of the main organizational goals and its valence as desirability of a particular outcome based on organizational value system). The concept of 'Adjustment' and its influence on the actual behavior was supported by study of Venkatesh and Bala (2008). As aforementioned, in typical family SMEs, an owner-manager CEO is dominantly responsible for driving the decision in the organization. Thus, their process-run-time evaluation of satisfaction (adjusted) was assumed as a potential EC adoption predictor. Accordingly, the following proposition is presented:

P6. Adjustment has a direct effect on EC adoption in Iranian family SMEs

\subsection{Intergenerational Successions}

There is a little-known on the implications of succession on the family SMEs' decisions and behaviors (Molly, 2009). Moreover, there is a range of controversy in terms of generational effects on family firms. Based on the organizational learning process during succession experiments it is assumed that family SMEs with more intergenerational successions, defined as changing the family in charge over generations, will more likely have a practice-learned business routine compared with their counterparts (Molly, 2009). This is aligned with study of Fernandez and Nieto (2005) and Diwisch, Voithofer and Weiss (2007) which addressed the significant positive effects of intergenerational successions on family SMEs' growth and internationalization. Moreover, according to Bjuggren and Sund (2001), the next generation family firms have a more survival chance, to hand over to the later generations, implying that in the intergenerational succession-elaborated family firms with the practice-learning sequence, the innovational behaviors' incidence is more predictable. Accordingly, the following proposition is presented:

P7. Intergenerational successions has a direct effect on EC adoption in Iranian family SMEs

\subsection{Perceived Organizational Resource}

Tan et al. (2007) defined Perceived Organizational Resource as the CEO's perception of human, financial, and technological resources' availability in the organization. Although this factor had been realized as an insignificant EC adoption factor in SMEs in some studies (Mirchandani \& Motwani, 2001; Scupola, 2003; Sarosa \& Underwood, 2005), it is assumed to be a basic preparation toward EC adoption and establishing the platform for its deployment. This is in line with studies of Grandon and Pearson (2004), Molla and Licker (2005), Sutanonpaiboon and Pearson (2006), and Chong (2006) in which the perceived organizational resource was referred as a significant factor for a successful EC adoption. This is moreover, supported by the study of Hajkarimi and Azizi (2008), Ghorishi (2009), Sanayei and Rajabion (2009), and Hajli and Bugshan (2012) in case of Iranian SMEs. Accordingly, the following proposition is presented:

P8. Perceived organizational resource has a direct effect on EC adoption in Iranian family SMEs. 


\subsection{Perceived Organizational Governance}

Perceived organizational governance, defined as the CEO's perception of the strategic, tactical, and operational models designing the organization's structure to establish objectives, allocate resources, and make decisions (Tan et al., 2007). It is referred to the CEO's perception of organizational structure; concerning gathering information and communicational ways, decision making, resource allocating, and decision implementation process (Seyal et al., 2004). The organizational governance in developing countries had been realized as an important EC deployment factor (Molla \& Licker, 2005). However, the empirical evidence from different developing countries showed inconsistent roles of organizational governance in EC adoption. While, the significance of organizational governance role for EC adoption was accepted in China, its importance was disproved in South Africa and Malaysia (Kurnia et al., 2009). Accordingly, the following proposition is presented:

P9. Perceived organizational governance has a direct effect on EC adoption in Iranian family SMEs.

\subsection{Perceived Organizational Supports}

In the related literature, the organizational support is constantly realized as a significant factor influencing EC adoption behavior both in developed countries (e.g., Grandon \& Pearson, 2004; Tsao et al., 2004; Sparling et al., 2007) or developing countries (e.g., Lertwongsatien \& Wongpinunwatana, 2003; Wu et al., 2003). This was moreover approved by the study of Ghorishi (2009) in case of Iranian SMEs. For the current study perceived organizational support, defined as CEO's perception of the availability of support within the organization. It is referred to the extent to which a CEO in family SMEs finds him/herself in a go-ahead relationship with members. However, in family SMEs, the organizational support for EC adoption might involve family's and also board of directors' support regarding to their vital 'advise' and 'control' roles in such SMEs. Accordingly, the following proposition is presented:

P10. Perceived organizational support has a direct effect on EC adoption in Iranian family SMEs.

\subsection{Perceived Industry Structure}

Perceived industry structure is defined as CEO's perception of nature and structure of an industry (Kurnia et al., 2009). It is referred to the CEO/Manager perception of industry structure, standards, inter-organizational nature of electronic commerce usage, interactions between adopting organizations and external institutions, and their mutual trust and dependencies as well as the power relationships and trading partners' readiness for promoting electronic commerce deployment. If in an industry a single standard of electronic data transfer is ruled and all parts of the industry work systematically together through coordinating bodies, lessening their issues and projecting their expectations, the electronic commerce deployment is increasingly extended. In the EC-related SMEs' literature, only few studies have explored the industry structure variable (Alzougool \& Kurnia, 2008; Kurnia et al., 2009). However, some EC-related studies on SMEs had independently explored a number of variables that are related to the industrial context level (e.g. Kaynak et al., 2005, Wymer \& Regan, 2005). In the case of Iranian SMEs, Abbasi et al. (2010) studied industry IT maturity. There is an evident lack of related studies for the influence of industry structure on EC adoption in family SMEs. Therefore, the following proposition is presented:

P11. Perceived industry structure has a direct effect on EC adoption in Iranian family SMEs.

\subsection{Perceived National (EC) Structure}

Perceived national (EC) structure defined as CEO's perception of availability of conducive infrastructural, cultural structure and supporting services that promotes adoption of electronic commerce in the country (Alzougool \& Kurnia, 2008; Kurnia et al., 2009). It is referred to EC structural readiness view under country-level lenses, concerning whether national structure, cultural and infrastructural, are translated to an operational EC delivery environment for the businesses. Only few studies have considered the national (EC) structure variable (e.g., Alzougool \& Kurnia, 2008). However, some EC-related studies had independently explored a number of variables that are related to the national context level, either in developed countries (e.g., Huy \& Filiatrault, 2006; Sarosa \& Underwood, 2005) or developing countries (e.g. Zhu et al., 2003). In case of Iranian SMEs, Ghobakhloo et al. (2011b), Afzal (2008), Sameni and Khoshalhan (2009), Sanayei and Rajabion (2009) have done some related studies. These studies indicated that the lack of national readiness, in terms of technological, social, cultural, legal, logistical, and financial structures, was the major inhibitor stalling the uptake of EC in developing countries. Accordingly, the following proposition is presented:

P12. Perceived (EC) national structure has a direct effect on EC adoption in Iranian family SME.

\subsection{Family (Strategic) Orientation}

Family (strategic) orientation defined as the extent to which the organizational mission is subjected to family 
oriented goals (extracted from; Uhlaner et al., 2007; Wang \& Ahmed, 2009; Molly, 2009). It is referred to the unique strategic orientation in family SMEs, categorizing them into 'Family-oriented' with a radical high family-orientated, overriding business values, and 'Value-oriented' with an optimized family and business values (Vilaseca, 2002). In fact, family SMEs tracks the mixture and diverse non-commercial concerns (such as having an excellent family communication) as well as the business concerns, adjusting their organizational objectives. In the literature, the 'business strategic orientation' with the different approaches had been frequently addressed in related studies such as Kaynak, Tatoglu and Kula (2005), Chong (2006), Huy and Filiatrault (2006) and Jeon et al. (2006). This was also considered in the related EC studies in family SMEs' context (i.e. Uhlaner et al., 2007). However, the 'family (strategic) orientation' as an exclusive orientation in family SMEs' context and its particular moderation effect on EC adoption in family businesses had been almost neglected (Wang \& Ahmed, 2009). Therefore, the particular moderation effects of 'family (strategic) orientation' on EC adoption antecedents were proposed as follow:

P13. 'Family (Strategic) Orientation' has a moderation effect on 'EC Adoption' in Iranian family SMEs.

\section{Conceptual Research Framework}

Based on the above literature review, a research framework was developed as a mean to examine the effects of the underlined factors on EC adoption in Iranian family SMEs. The relationship between the underlined potential factors and EC adoption in such businesses is illustrated in Figure 1.

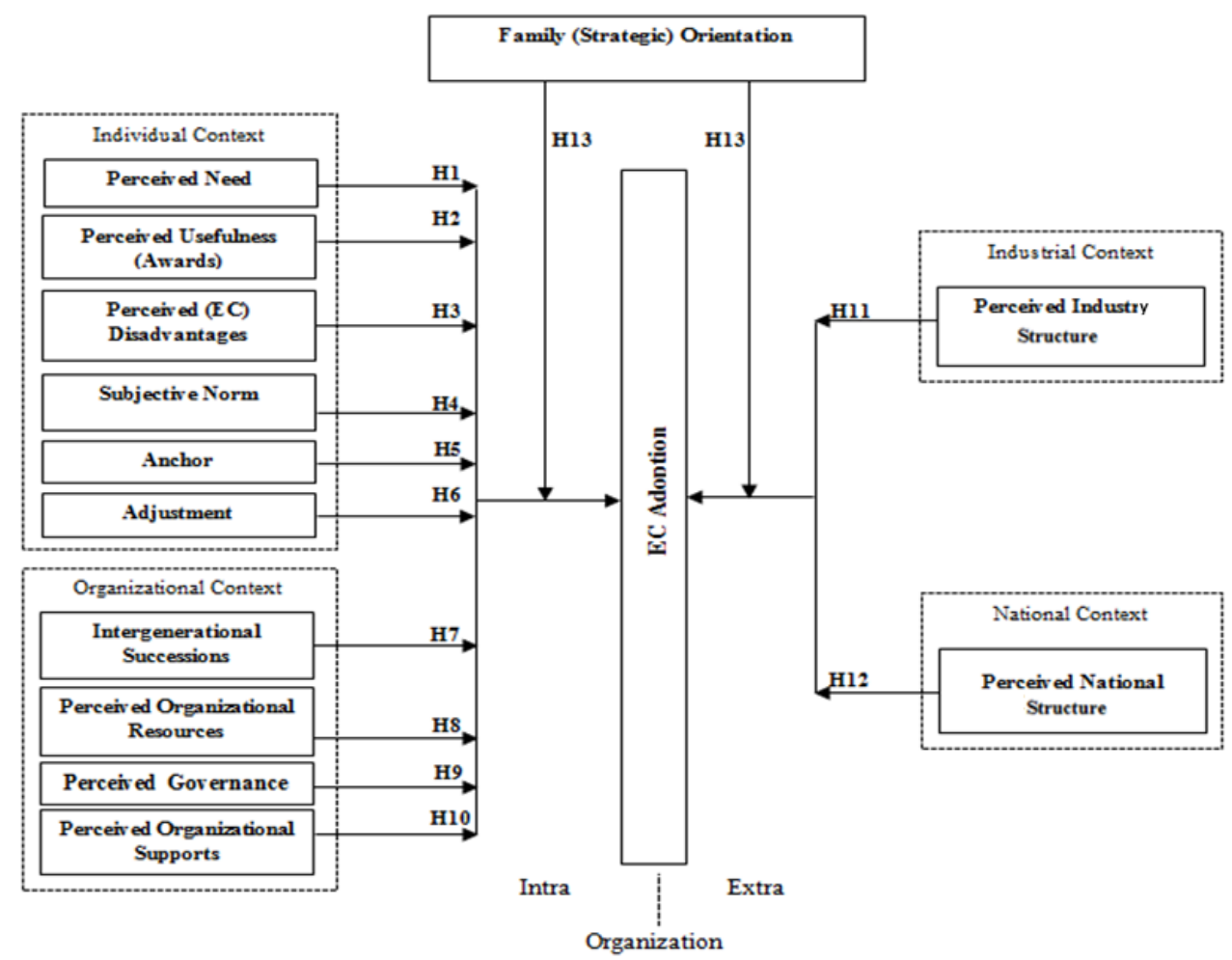

Figure 1. The relationship between the underlined potential factors and EC adoption

The theoretical framework includes twelve independent factors under four 'Individual', "Organizational', Industrial', and 'national' contexts, and one moderator factor by which the relationship between the independent factors and EC adoption as dependent variable is affected. The proposed model supports the view that organizations need to deal with multiple factors influencing EC. The model indicates that extension of EC adoption associates with the greatness of the perceived factors (other than "Perceived Disadvantages' factor with a reverse effect).

\section{Theoretical Implication}

The study suggest there is an interconnection in EC adoption, Family (Strategic) Orientation, and CEO Perceptions of readiness; individually, organizationally, and nationally. It means both CEOs Individual readiness for electronic commerce and their perceived structure of national and company governance for EC should be 
taken into consideration in case of extension of EC deployment in Iranian family SMEs. CEO 'Perceived Usefulness' needs to be enhanced even more for the purpose of making EC deployment easier in Iranian family SMEs. Perhaps, the next item would be 'Organizational Supports' to consider for having a better EC adoption process in family SMEs in Iran.

\section{Managerial Implication}

In relation to electronic commerce, quite negligible consideration had been given to the importance of observing the conveyance of related activities to the wider and more diversified range of external 'business-linked' and/or 'customer-linked' business relationships, over Internet and Website technological structure', yet such valuations were projected to be critical for the business. Therefore, 'EC adoption' in the current study reflected the significance of 'Extent of Deployment' (outwardly/Inwardly), by looking at 'Volume' as the degree of business, derived from B2B/B2C Internet/Web-based EC (Conducted Online), 'Diversity' as the degree of variety in business functions, conducted by B2B/B2C Internet/Web-based EC (in concern with their trading partners, suppliers and customers), and 'Breadth' as extent to which the EC connections were developed with trading partners, suppliers and customers (Khoje et al., 2013).

EC encouraging strategy and guidelines with the purpose of the press forward EC adoption in family SMEs in Iran should be contingent on collecting data on the present EC-associated observes, complications, and promises in such distinct Iranian SMEs. Reasonably, the proposed model delivered incentive for Iranian family SMEs to adopt operational EC practices in their business. By realization of the particular factors influencing EC adoption in Iranian family SMEs, this research delivered coherent information to re-arrange the resources in Iranian EC developing agencies; such as BAS (Business Advisory Service), BIC (Business Innovation Centre), Training Centre, Business Associations and Incub Centre (Innovation Centre) more competently, in order to boost EC adoption in such Iranian SMEs.

By understanding the point that, some unique distinctiveness in family SMEs might be detrimental to their embarking on e-business practices, it is suitable to invest in identifying and exploring special effects of EC adoption potential predictors in practice in such distinct SMEs in Iran. To this end, the proposed model will demonstrate its value.

\section{Conclusion}

In conclusion, the current research contributed to the electronic commerce literature by linking EC practices to the underlying 'Volume' as the degree of business, derived from B2B/B2C Internet/Web-based EC (Conducted Online), 'Diversity' as the degree of variety in business functions, conducted by B2B/B2C Internet/Web-based EC (in concern with their trading partners, suppliers and customers), and 'Breadth' as extent to which the EC connections were developed with trading partners, suppliers and customers.

CEO Perceptions of readiness factors; organizationally and nationally indeed have a great impact on EC adoption in the SMEs and particularly Family SMEs in Iran. CEOs perception of Individual readiness might also influence EC adoption in such distinct Iranian businesses; however this possibility had been indicated in little studies. Therefore, this paper mainly targeted to propose a rather comprehensive conceptual model for EC adoption in Iranian family SMEs. It was predictable that the more the degree to which the EC predictors exist, the higher Electronic commerce may adopt (measured by EC Volume, EC Diversity, and EC Breadth) in such distinct SMEs in Iran, except than EC Disadvantages with a reversed effect.

The current paper proposed a model to investigate main first potential factors under four 'Individual', "Organizational', Industrial', and 'national' contexts, and the effect of 'family strategic orientation' as the moderator of EC adoption. They were important factors in conveying wider and more diversified range of external 'business-linked' and/or 'customer-linked' business relationships, over Internet and Website technological structure'. This research was an opening effort to discover the association between CEO perception of individual readiness factors such as "anchor" and "adjustment" in EC adoption in family SMEs' domain. To create the run-through model, supplementary analysis and examination will be accompanied using Structural Equation Modeling for model examining, validation and improvement.

\section{References}

Abbasi, M., Sarlak, M., Ghorbani, A., \& Esfehani, H. (2010). CSFs of e-commerce admission in small and medium size enterprises (SMEs). Africa Journal of Business Management, 4(16), 3480-3490.

Afzal, H. (2008). EC adoption and Critical Success factors of EC in SMEs in Iran, Lulea University of Technology. Master Thesis. 
Ajdari, B. (2007). Impact of e-Commerce on internationalization of Iranian SMEs, Lulea University of Technology. Master Thesis.

Ajzen, I. (1991). The theory of planned behavior. Organizational Behavior and Human Decision Processes, 50(2), 179-211. http://dx.doi.org/10.1016/0749-5978(91)90020-T

Alzougool, B., \& Kurnia, S. (2008). EC Technologies Adoption by SMEs: A Conceptual Study, 19th Australasian Conference on Information Systems. Christchurch, New Zealand.

Astrachan, J., \& Jaskiewicz, P. (2008). Emotional returns and emotional costs in privately held family businesses: Advancing traditional business valuation. Family Business Review, 21, 139-149. http://dx.doi.org/10. 1111/j.1741-6248.2008.00115.x

Bandura, A. (1986). Social foundations of thought and action: A social cognitive theory. Prentice-Hall, Englewood Cliffs, NJ.

Barclays Wealth and the Economist Intelligence Unit. (2009). Barclays Wealth Insights (Vol. 8). Family Business: In Safe Hands?

Bjuggren, P., \& Sund, L. (2001). Strategic decision making in Intergenerational Successions of small and medium-size family-owned businesses. Family Business Review, 14(1), 11-23. http://dx.doi.org/10.1111/ j.1741-6248.2001.00011.x

Carayannis, E., \& Turner, E. (2006). Innovation diffusion and technology acceptance: The case of PKI technology. Technovation, 26(7), 847-855. http://dx.doi.org/10.1016/j.technovation.2005.06.013

Celuch, K., Goodwin, S., \& Taylor, S. (2007). Understanding small scale industrial user Internet purchase and information management intentions: A test of two attitude models. Industrial Marketing Management, 36(1), 109-120. http://dx.doi.org/10.1016/j.indmarman.2005.08.004

Chong, S. (2006). An Empirical Study of Factors that Influence the Extent of Deployment of Electronic Commerce for Small and Medium sized Enterprises in Australia. Journal of Theoretical and Applied Electronic Commerce Research, 1(2), 47-57.

Chong, S. (2008). Success in Electronic Commerce Implementation: A Cross-country of Small and Medium-sized Enterprises. Journal of Enterprise Information Management, 21(5), 468-492. http://dx.doi.org/10.1108/ 17410390810904247

Chrisman, J., Chua, J., \& Sharma, P. (2003). Current trends and future directions in family business management studies: Toward a theory of the family Business. written as part of Coleman Foundation White Paper Series.

Daniel, E., \& Grimshaw, D. (2002). An exploratory comparison of electronic commerce adoption in large and small enterprises. Journal of Information Technology, 17, 133-147. http://dx.doi.org/10.1080/02683960 22000018409

Davis, F. (1989). Perceived usefulness, perceived ease of use, and user acceptance of information technology. MIS Quarterly, 13(3), 319-340. http://dx.doi.org/10.2307/249008

Dawkins, C., \& Frass, J. (2005). Decision of union workers to participate in employee involvement: An application of the theory of planned behavior. Employee Relations, 27(5), 511-531. http://dx.doi.org/10.11 08/01425450510612031

Dholakia, R., \& Kshetri, N. (2004). Factors impacting the adoption of internet among SMEs. Small Business Economics, 23(4), 311-322. http://dx.doi.org/10.1023/B:SBEJ.0000032036.90353.1f

Diwisch, D., Voithofer, P., \& Weiss, C. (2007). Succession and firm growth: Results from a non-parametric matching approach. Small Business Economics. http://dx.doi.org/10.1007/s11187-007-9072-z

Donckels, R., \& Frohlick, E. (1991). Are family businesses really different? European experiences from STRATOS. Family Business Review, 4(2), 149-160. http://dx.doi.org/10.1111/j.1741-6248.1991.00149.x

Doolin, B., McLeod, L., McQueen, B., \& Watton, M. (2003). Internet strategies for establishing retailers: Four New Zealand case studies. Journal of Information Technology Cases and Applications, (5/4), 3-19. http://dx.doi.org/10.1080/15228053.2003.10856030

Dunn, B. (1995). Success themes in Scottish family enterprises: Philosophies and practices through the generations. Family Business Review, 8(1), 17-28. http://dx.doi.org/10.1111/j.1741-6248.1995.00017.x

European Commission. (2009). Enterprise and Industry, Directorate-General promotion Of SMEs' Competitiveness, Final Report of the Expert Group overview of Family-Business-Relevant Issues: Research. 
Networks, Policy Measures and existing Studies.

Fernandez, Z., \& Nieto, M. (2005). Internationalization strategy of small and medium-sized family businesses: Some influential factors. Family Business Review, 18(1), 77-89. http://dx.doi.org/10.1111/j.1741-6248.2005. 00031.x

Fishbein, M., \& Ajzen, I. (1975). Belief, attitude and behavior: An introduction to theory and research. Reading, MA: Addison-Wesley.

Gersick, K., Davis, J., Hampton, M., \& Lansberg, I. (1997). Generation to Generation: Life cycles of the family business. Boston Massachusetts: Harvard Business School Press.

Ghamatrasa, M. (2006). Internet Adoption Decision Model among Iranian Small and Medium Enterprises. Lulea University of Technology, Master Thesis.

Ghobakhloo, M., Arias-Aranda, D., \& Benitez-Amado, J. (2011a). Information technology implementation success within SMEs in developing countries: An interactive model. POMS 22nd Annual Conference: Operations management: The enabling link Reno, Nevada, U.S.A.

Ghobakhloo, M., Arias-Aranda, D., \& Benitez-Amado, J. (2011b). Adoption of e-commerce applications in SMEs. Industrial Management \& Data Systems, 111(8), 1238-1269. http://dx.doi.org/10.1108/02635571111170785

Ghorishi, M. (2009). E-Commerce Adoption Model in Iranian SMEs. Lulea University of Technology, Master Thesis.

Gibbs, J., \& Kraemer, K. (2004). A Cross-Country Investigation of the Determinants of Scope of Ecommerce Use: An Institutional Approach. Electronic Markets, (12/2), 124-137. http://dx.doi.org/10.1080/10196780410 001675077

Gomez, L. S. (2012). Innovation Adoption in Family Businesses from Developing Countries: The Case of Colombia. Paper presented at the annual meeting of the SASE Annual Conference 2012, M.I.T., Cambridge, MA.

Grandon, E., \& Pearson, J. (2004). E-commerce adoption: Perceptions of managers/owners of small and medium sized SMEs in Chile. Communications of the Association for Information Systems, (13), 81-102.

Hajiha, A., Ghaffari F., \& Hajihashemi, L. (2010). The Survey of Effective Behavioral Factors on Decision Making of Acceptance the Electronic Commerce, by Managers of SMEs in Tehran. Journal of Management Research, 20(83), 17-31.

Hajkarimi A., \& Azizi, Sh. (2008). Model of Factors Affecting E-Commerce Adoption in Small Businesses. Iranian Journal of Trade Studies, 12(48), 191-229.

Hajli, M., \& Bugshan, H. (2012). E-Commerce Pre-Adoption Model for SMEs in Developing Countries. Proceedings of the 2012 International Conference on e-Learning, e-Business, Enterprise Information Systems, and e-Government, Las Vegas, United States.

Harrison, D., Mykytyn, P., \& Riemenschneider, C. (1997). Executive decisions about adoption of information technology in small business: Theory and empirical tests. Information Systems Research, 8(2), 171-195. http://dx.doi.org/10.1287/isre.8.2.171

Hersey, P., \& Blanchard, K. (1993). Management of Organizational Behavior: Utilizing Human Resources (6th ed.). Englewood Cliffs, NJ: Prentice-Hall Inc.

Hussin, H., \& Al-Musowi, A. (2006). E-commerce adoption by Oman organizations: A descriptive analysis on the status and perceived barriers. Paper presented at the Information Communication Technology for Muslim World (ICT4M) 2006, Kuala Lumpur Malaysia.

Huy, L., \& Filiatrault, P. (2006). The Adoption of E-commerce in SMEs in Vietnam: A Study of Users and Prospectors. In Proceedings of the 10th Pacific Asia Conference on Information Systems (pp. 1335-1344).

Iacovou, C., Benbasat, I., \& Dexter, A. (1995). Electronic data interchange and small organizations: Adoption and impact of technology. MIS Quarterly, 19(4), 465-485. http://dx.doi.org/10.2307/249629

IFERA. (2003). Family businesses dominate. Family Business Review, 16(4), 235-240.

Igbaria, M., Zinatelli, N., Cragg, P., \& Cavaye, A. (1997). Personal computing acceptance factors in small firms: A structural equation model. MIS Quarterly, 21(3), 279-305. http://dx.doi.org/10.2307/249498

Jamali, S. K., Samadi, B., \& Gharleghi, B. (2015). Factors Influencing Electronic Commerce Adoption: A Case 
Study of Iranian Family SMEs. International Journal of Business and Social Science, 6(2).

Jamali, S. K., Samadi, B., \& Marthandan, G. (2014). Prioritizing Electronic Commerce Technologies in Iranian Family SMEs. Interdisciplinary Journal of Contemporary Research in Business, 6(2).

Jeon, B., Han, K., \& Lee, M. (2006). Determining factors for the adoption of e-business: The case of SMEs in Korea. Applied Economics, (38/16), 1905-1916. http://dx.doi.org/10.1080/00036840500427262

Johnston, D., Wade, M., \& McClean, R. (2007). Does e-business matter to SMEs? A comparison of the financial impacts of internet business solutions on European and North American SMEs. Journal of Small Business Management, 45(3), 354-361. http://dx.doi.org/10.1111/j.1540-627X.2007.00217.x

Kartiwi, M. (2006). Case Studies of E-commerce Adoption in Indonesian SMEs: The Evaluation of Strategic Use. Australasian Journal of Information Systems, (14/1), 69-80. http://dx.doi.org/10.3127/ajis.v14i1.8

Kartiwi, M., \& McGregor, R. (2007). Electronic commerce adoption barriers in small to medium-sized enterprises (SMEs) in developed and developing countries: A cross-country comparison. Journal of Electronic Commerce in Organizations, 5(3), 35-51. http://dx.doi.org/10.4018/jeco.2007070103

Kaynak, E., Tatoglu, E., \& Kula, V. (2005). An analysis of the factors affecting the adoption of electronic commerce by SMEs: Evidence from an emerging market. International Marketing Review, (22/6), 623-640.

Khojeh, Ehsan, Mohseni, S., \& Samadi, B. (2013). Enhancing Customer Satisfaction among SMEs through Web Technology. Research Notes in Information Science, 11, 13-28

KMU Forschung Austria. (2008). Overview of family business relevant issues. Vienna (p. 1).

Kotey. (2005). Are performance differences between family and non-family SMEs uniform across all firm sizes? International Journal of Entrepreneurial Behavior \& Research, 11(6), 394-421.

Krueger, N. (1993). The Impact of Prior Entrepreneurial Exposure on Perceptions of New Venture Feasibility and Desirability. Entrepreneurship Theory and Practice (pp. 5-21).

Krueger, N., Reilly, M., \& Carsrud, A. (2000). Competing models of entrepreneurial intentions. Journal of Business Venturing, 15(5), 411-432. http://dx.doi.org/10.1016/S0883-9026(98)00033-0

Kula, V., \& Tatoglu, E. (2003). An exploratory study of Internet adoption by SMEs in an emerging market economy. European Business Review, (15/5), 324-333. http://dx.doi.org/10.1108/09555340310493045

Kurnia, S., \& Johnston, R. (2003). Adoption of Efficient Consumer Response: Key Issues and Challenges in Australia, Supply Chain Management. An International Journal, (8/2), 251-262.

Kurnia, S., Alzougool, B., Ali, M., \& Alhashmi, S. (2009). Adoption of Electronic Commerce Technologies by SMEs in Malaysia. In Proceedings of the 42nd Hawaii International Conference on System Sciences.

La Porta, R., Lopez, D., \& Shleifer, F. (1999). Corporate Ownership around the World. Journal of Finance, 54(2), 471-517. http://dx.doi.org/10.1111/0022-1082.00115

Lawson, R., Alcock, C., Cooper, J., \& Burgess, L. (2003). Factors affecting adoption of electronic commerce technologies by SMEs: An Australian study. Journal of Small Business and Enterprise Development, 10(3), 265-276. http://dx.doi.org/10.1108/14626000310489727

Leach, P. (1994). The Stoy Hayward Guide to Family Business. London: Kogan Page.

Leach, P., Smith, W., Hart, A., Morris, T., Ainsworth, J., Beterlsen, E., ..., Pasari, V. (1990). Managing the family business in the UK: Stoy Hayward Survey in conjunction with the London Business School. Stoy Harward, London.

Lee, G., \& Xia, W. (2006). Organizational size and IT innovation adoption: A meta-analysis. Information and Management, (43/8), 975-985. http://dx.doi.org/10.1016/j.im.2006.09.003

Lee, J., \& Runge, J. (2001). Adoption of information technology in small business: Testing drivers of adoption for entrepreneurs". Journal of Computer Information Systems, (42/1), 44-57.

Lertwongsatien, C., \& Wongpinunwatana, N. (2003). E-Commerce Adoption in Thailand: An Empirical Study of Small and Medium Enterprises (SMEs). Journal of Global Information Technology Management, (6/3), 67-82. http://dx.doi.org/10.1080/1097198X.2003.10856356

Lim, N. (2003). Consumers' perceived risk: sources versus consequences. Electronic Commerce Research and Applications, 2(3), 216-228. http://dx.doi.org/10.1016/S1567-4223(03)00025-5

Lin, F., \& Wu, J. (2004). An empirical study of end-user computing acceptance factors in small and medium 
enterprises in Taiwan: Analyzed by structural equation modeling. Journal of Computer Information Systems, 44(3), 98-108.

Lohrke, F., Kreiser, P., \& Weaver, K. (2006). The influence of current Business performance on future SME alliance formation intentions: A six-country study. Journal of Business Research, 59(1), 19-27. http://dx.doi. org/10.1016/j.jbusres.2005.02.002

Looi, H. (2005). E-commerce adoption in Brunei Darussalam: A quantitative analysis of factors influencing its adoption, Communications of the Association for Information. Systems, 15, 61-81.

Meftah, M., Gharleghi, B., \& Samadi, B. (2015). Adoption of E-Government among Bahraini Citizens. Asian Social Science, 11(4), 141. http://dx.doi.org/10.5539/ass.v11n4p141

Mirchandani, D., \& Motwani, J. (2001). Understanding small business electronic commerce adoption: An empirical analysis. Journal of Computer Information Systems, (41/3), 70-73.

Molla, A., \& Licker, P. (2005). Perceived E-Readiness factors in Ecommerce adoption: An empirical investigation in a developing country. International Journal of Electronic Commerce, 10(1), 83-110.

Molly, V. (2009). The heterogeneity of the family business: Goal orientation, Intergenerational differences and Succession. Doctoral dissertation, Antwerpen University, Belgium.

Nasco, S., Toledo, E., Mykytyn, Jr., \& Peter, P. (2008). Predicting EC adoption in Chilean SMEs. Journal of Business Research Strategic Management in Latin America, (61/6), 697-705.

Niehm, L., Tyner, K., Shelley, M., \& Fitzgerald, M. (2010). Technology Adoption in Small Family-Owned Businesses: Accessibility, Perceived Advantage, and Information Technology Literacy. Journal of Family and Economic Issues, 31(4), 498-515. http://dx.doi.org/10.1007/s10834-010-9197-0

Nogoev, A., Yazdanifard, R., Mohseni, S., Samadi, B., \& Menon, M. (2011). The Evolution and Development of E-Commerce Market and E-Cash. In International Conference on Measurement and Control Engineering 2nd (ICMCE 2011). ASME Press. http://dx.doi.org/10.1115/1.859858.paper35

Oliveira, T., \& Martins, M. (2011). Literature Review of Information Technology Adoption Models at Firm Level. The Electronic Journal Information Systems Evaluation, 14(1), 110-121.

Riemenschneider, C., \& McKinney, V. (2001-2002). Assessing belief differences in small business adopters and Non-adopters of web-based e-commerce. Journal of Computer Information Systems, 101-107.

Riemenschneider, C., Harrison, D., \& Mykytyn, P. (2003). Understanding IT adoption decisions in small business: integrating current theories. Information \& Management, 40, 269-285. http://dx.doi.org/10.1016/S0378-7206 (02)00010-1

Roberts, B., \& Toleman, M. (2007). One-size e-business adoption model does not fit all. Journal of Theoretical and Applied Electronic Commerce Research, 2(3), 49-61.

Rogers, E. (1983). Diffusion of innovation (3rd ed.). New York: the Free Press.

Rogers, E. (1995). Diffusion of innovation (4th ed.). New York: the Free Press.

Rogers, E. (2003). Diffusion of innovation (5th ed.). New York: the Free Press.

Sam, T., \& Leng, A. (2006). Adoption of electronic commerce amongst small and medium enterprise. Paper presented at the Knowledge Management International Conference and Exhibition 2006, Kuala Lumpur Malaysia.

Sameni, M., \& Khoshalhan, F. (2009). E-Business Adoption in Iranian Small and Medium Enterprises: Analyzing and Prioritizing the Extra-Organizational Factors. PICMET, Proceedings, Portland, Oregon USA. http://dx.doi.org/10.1109/PICMET.2009.5261946

Sanayei, A., \& Rajabion, L. (2009). Critical Successful Factors Contributing to E-Commerce Adoption among Iranian SMEs. International Journal of Information Science and Management, 7(2).

Sarosa, S., \& Underwood, J. (2005). Factors affecting IT adoption within Indonesian SMEs: Manager's perspectives. In Proceedings of the 9th Pacific Asia Conference on Information Systems (pp. 7-10). Bangkok, Thailand.

Scupola, A. (2003). The adoption of Internet commerce by SMEs in the South Italy: An environmental, technological and organizational perspective. Journal of Global Information Technology Management, (6/1), 52-71. http://dx.doi.org/10.1080/1097198X.2003.10856343 
Seyal, A., Awais, M., Shamail, S., \& Abbas, A. (2004). Determinants of Electronic Commerce in Pakistan: Preliminary Evidence from Small and Medium Enterprises. Electronic Markets, (14/4), 372-387. http://dx.doi.org/10.1080/10196780412331311801

Shanker, M., \& Astrachan, J. (1996). Myths and realities: Family businesses' contribution to the US economy - a framework for assessing family business statistics. Family Business Review, 9(2), 107-123. http://dx.doi. $\operatorname{org} / 10.1111 / j .1741-6248.1996 .00107 . x$

Sharma, P., Chrisman, J., \& Chua, J. (1996). A Review and Annotated Bibliography of Family Business Studies. Kluwer Academic Publishers, Boston. http://dx.doi.org/10.1007/978-1-4419-8768-6

Sharma, P., Chrisman, J., \& Chua, J., (1997). Strategic management of the family business: Past research and future challenges. Family Business Review, 10(1), 1-36. http://dx.doi.org/10.1111/j.1741-6248.1997.00001.x

Sophonthummapharn, K. (2008). A Comprehensive Framework for the Adoption of Techno-Relationship Innovations: Empirical Evidence from E-CRM in Manufacturing SMEs. Umeå School of Business, Umeå University, Sweden.

Sparling, L., Toleman, M., \& Cater-Steel A. (2007). SME Adoption of e-Commerce in the Central Okanagan Region of Canada. In Proceedings of the 18th Australasian Conference on Information Systems (pp. 1046-1059). Toowoomba, Australia.

Sulaiman, A. (2000). The status of e-commerce applications in Malaysia. Information Technology for Development, 9, 153-161. http://dx.doi.org/10.1080/02681102.2000.9525329

Sutanonpaiboon, J., \& Pearson, A. (2006). E-Commerce Adoption: Perceptions of Managers/Owners of Small-and Medium-Sized Enterprises (SMEs) in Thailand. Journal of Internet Commerce, 5(3), 53-82. http://dx.doi. org/10.1300/J179v05n03_03

Tan, J., Tyler, K., \& Manica, A. (2007). Business-To- Business Adoption of E-Commerce in China. Information \& Management, 44(3), 332-351. http://dx.doi.org/10.1016/j.im.2007.04.001

Teo, T., \& Ranganathan, C. (2004), 'Adopters and non-adopters of business-to-business electronic commerce in Singapore'. Information and Management, 42, 89-102. http://dx.doi.org/10.1016/j.im.2003.12.005

Thong, J. (1999). An integrated model for information systems adoption in small businesses. Journal of Management Information Systems, 15(4), 187-214.

Tornatzky, L., \& Klein, K. (1982). Innovation characteristics and innovation adoption-implementation: A meta-analysis of findings. IEEE Transactions on Engineering Management, 29(1), 28-45. http://dx.doi.org/ 10.1109/TEM.1982.6447463

Tsao, H., Lin, K., \& Lin, C. (2004). An investigation of critical success factors in the adoption of B2B EC by Taiwanese companies. Journal of American Academy of Business, (5/1), 198-202.

Tversky, A., \& Kahneman, D. (1974). Judgment under uncertainty: Heuristics and biases. Science, 185, 1124-1130. http://dx.doi.org/10.1126/science.185.4157.1124

Tversky, A., \& Kahneman, D. (1991). Advances in Prospect Theory: Cumulative Representation of Uncertainty. Stanford University.

Uhlaner, L., Tan, S., \& Meijaard, J. (2007). Family Orientation, Strategic Orientation and Innovation Performance in SMEs: A Test of Lagged Effects. SCALES-initiative, Scientific Analysis of Entrepreneurship and SMEs.

Venkatesh, V., \& Bala, H. (2008). Technology Acceptance Model 3 and a Research Agenda on Interventions. Decision Sciences, 39(2), 272-315. http://dx.doi.org/10.1111/j.1540-5915.2008.00192.x

Venkatesh, V., \& Davis, F. (2000). A theoretical extension of the technology acceptance model: Four longitudinal field studies. Management Science, 46(2), 186-204. http://dx.doi.org/10.1287/mnsc.46.2.186.11926

Venkatesh, V., Morris, M., Davis, F., \& Davis, G. (2003). User Acceptance of Information Technology: Toward a Unified View. MIS Quarterly, 27, 425-478.

Vilaseca, A. (2002). The shareholder role in the family business: Conflict of interests and objectives between non-employed shareholders and top management team. Family Business Review, 15(4), 299-320. http://dx.doi.org/10.1111/j.1741-6248.2002.00299.x

Wang, Y., \& Ahmed, P. (2009). The moderating effect of the business strategic orientation on ecommerce adoption: Evidence from UK family run SMEs. Journal of Strategic Information Systems, 18, 16-30. http://dx.doi.org/ 
10.1016/j.jsis.2008.11.001

Welsh, D., \& Zellweger, T. (2010). Can We Afford it? Reference Point Dependent Investment Decisions of Family and Nonfamily Owners. Allied Academies, Whitney Press.

Wu, F., Mahajan, V., \& Balasubramanian, S. (2003). An analysis of e-business adoption and its impact on business performance. Journal of the Academy of Marketing Science, (31/4), 425-447. http://dx.doi.org/10.1177/ 0092070303255379

Wu, J., \& Wang, S. (2005). What Drives Mobile Commerce? An Empirical Evaluation of the Revised Technology Acceptance Model. Information \& Management, 42(5), 719-729. http://dx.doi.org/10.1016/j.im.2004.07.001

Wymer, S., \& Regan, E. (2005). Factors influencing e-commerce adoption and use by small and medium businesses. Electronic Markets, (15/4), 438-453. http://dx.doi.org/10.1080/10196780500303151

Zhu, K., Kraemer, K., \& Xu, S. (2003). Electronic business adoption by European SMEs: A cross-country assessment of the facilitators and inhibitors. European Journal of Information Systems, 12(4), 251-268. http://dx.doi.org/10.1057/palgrave.ejis.3000475

Zohoori, M., Mohseni, S., \& Samadi, B. (n. d.). The Relationship between Knowledge Sharing and Innovation in Electronic Industry of Iran.

\section{Appendixes}

\section{Appendix A}

Table A1. EC and EC-related technologies adoption factors, studied in SMEs' \& family SMEs' context or suggested in the common related models

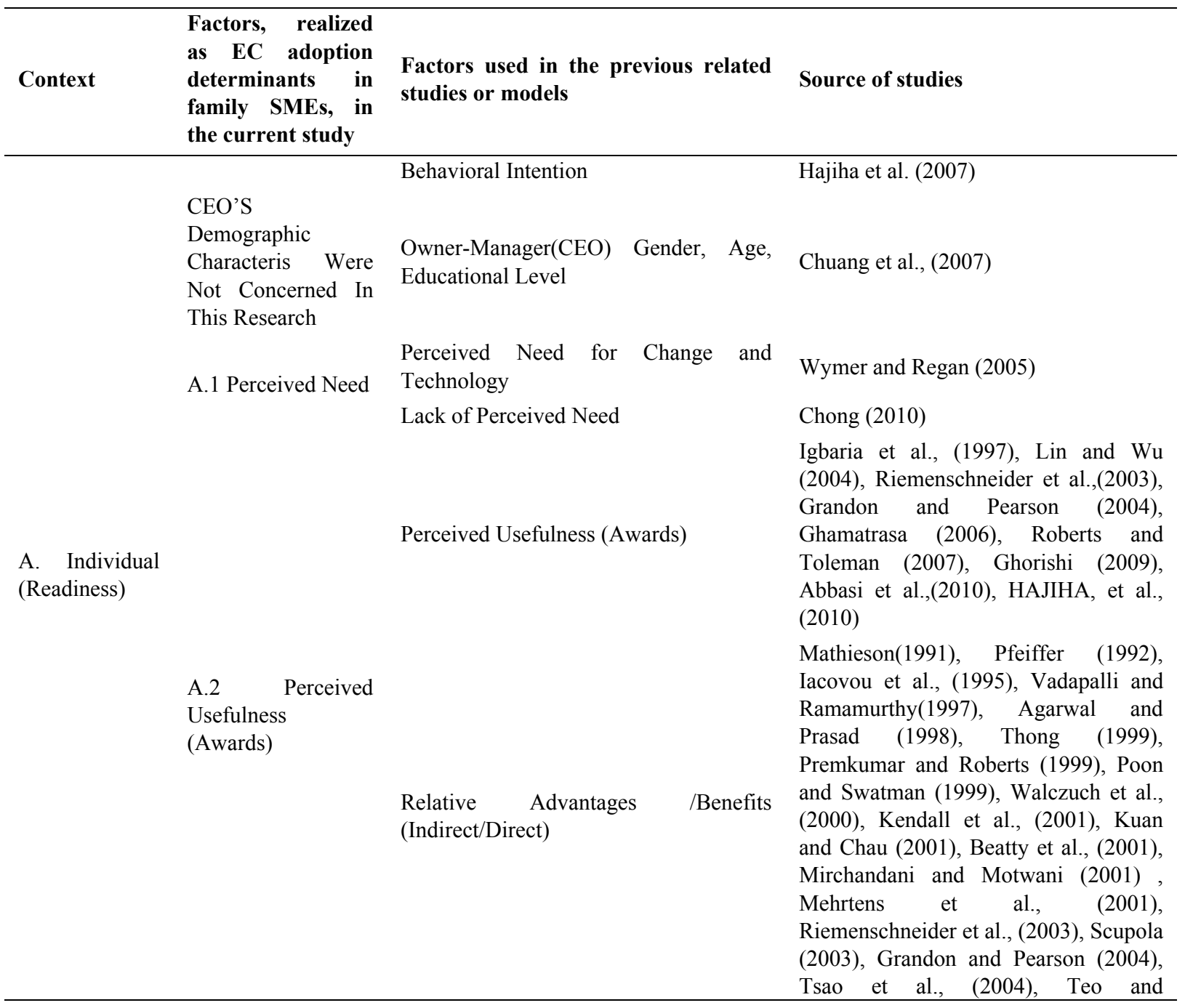




\begin{tabular}{ll}
\hline & Factors, realized \\
as EC adoption & \\
determinants in Factors used in the previous related \\
family SMEs, in studies or models \\
the current study
\end{tabular}

Compatibility

Trialability

Observability

Reliability (of Technology)

Output Quality

Job Relevance

Result Demonstrability

Image

A.3 Perceived Security Issues

Disadvantages

(Risk)

Perceived Risk

$\begin{array}{ll}\text { A.4 Subjective } & \text { Subjective Norm } \\ \text { Norm } & \end{array}$

\section{Source of studies}

Ranganathan (2004), Seyal et al., (2004), Kaynak et al., (2005), Chwelos et al., (2005), Looi (2005), Al-Qirim (2005), Huy and Filiatrault (2006), Jeon et al.,(2006), Chong (2006) Ghamatrasa (2006), Afzal (2008), Kurnia and Alzougool, (2008), , Hajkarimi and Azizi (2008), Sanayei and Rajabion (2009), Sameni and Khoshalhan (2009), Ghorishi (2009), Wang and Ahmed (2009), Abbasi et al.,(2010), Ifnedo (2011), Ghobakhloo et al.,(2011b)

Thong (1999), Karahanna et al.,(1999), Beatty et al., (2001), Mirchandani and Motwani (2001), Kendall et al., (2001),Wu and Sawy (2003), Ching and Ellis (2004), Teo and Ranganathan (2004), Grandon and Pearson (2004), Al-Qirim (2005), Wu and $\mathrm{Wu}$ (2005), Jeon et al.,(2006), Huy and Filiatrault (2006), Chong (2006), Sparling et al., (2007), Al-Qirim (2007), Afzal (2008), Sameni and Khoshalhan (2009), Ghobakhloo et al.,(2011b)

Kendall et al., (2001), Wu and Sawy (2003), Zhang and Huang (2004), Wu and $\mathrm{Wu}$ (2005), Chong (2006), Sameni and Khoshalhan (2009)

Karahanna et al., (1999), Wu and Wu (2005), Chong (2006), Sameni and Khoshalhan (2009)

Wymer and Regan (2005), Sameni and Khoshalhan ( 2009)

Walezuch et al., (2000), Philips (2002), Wymer and Regan (2005), Looi (2005), Ghamatrasa (2006), Sameni and Khoshalhan (2009), Iddris (2012)

Alzougool and Kurnia (2008), Hajkarimi and Azizi (2008)

Harrison D. et al., (1997), Venkatesh and Davis(2000), Riemenschneider and McKinney (2001-2002), Kula and Tatoglu (2003), Riemenschneider et al., (2003), Sarosa and Underwood (2005), Dawkins and Frass (2005), Ghamatrasa (2006), Celuch et al., (2007), Nasco et al., (2008), Abbasi et al.,(2010), Niehm et al., (2010), HAJIHA, et al., (2010) 


\begin{tabular}{ll}
\hline & Factors, realized \\
as EC adoption \\
determinants in Factors used in the previous related \\
family SMEs, in studies or models \\
the current study
\end{tabular}

Perceived External (Out of Organization) Pressures (Expectation) [Industry, Competitive, Government, Buyers/Consumer, Suppliers, Social]:

Perceived Internal (Intra-Organization) Pressures (Expectation)[Members, Family]

Voluntariness

Attitude

Anxiety

Affect

A.5 Anchor

Perceived Behavioral Control

Perception of External Control

Complexity

\section{Source of studies}

Iacovou et al., (1995), Premkumar and Roberts (1999), Kurnia and Johnston (2000), Kuan and Chau (2001), Chang and Cheung (2001), Mehrtens et al., (2001), Mirchandani and Motwani (2001), Ling (2001), Chwelos et al., (2001), Riemenschneider and McKinney(2001) Riemenschneider and McKinney (2002), Zhu et al.,(2003), Kula and Tatoglu (2003), Doolin et al., (2003), Scupola (2003), Lertwongsatien and Wongpinunwatana (2003), Lee (2004), Dholakia and Kshetri (2004), Grandon and Pearson (2004), Teo and Ranganathan (2004), Seyal et al., (2004), Zhu and Kraemer (2005), Wymer and Regan (2005), Sarosa and Underwood(2005), Looi (2005), Kaynak et al., (2005), Huy and Filiatrault (2006), Jeon et al., (2006), Chong (2006), Al-Qirim (2005,2007), Sparling et al., (2007), Kurnia and Alzougool (2008), Afzal (2008), Nasco et al., (2008), Sanayei and Rajabion (2009), Sameni and Khoshalhan (2009), Ghorishi (2009), Wang and Ahmed (2009), Ifnedo (2011), Ghobakhloo et al.,(2011b)

Kurnia and Alzougool (2008), Kurnia et al. (2009)

\section{Venkatesh and Bala (2008)}

Ajzen (1991), Harrison D. et al., (1997), Kula and Tatoglu (2003),Olson and Boyer (2003), Kula and Tatoglu (2003), Sarosa and Underwood (2005), Nasco et al., (2008), Niehm et al., (2010), HAJIHA, et al., (2010)

Venkatesh and Bala (2008)

Riemenschneider and McKinney (2001-2002), Nasco et al.,(2008), HAJIHA, et al., (2010)

Venkatesh and Bala (2008)

Thompson et al., (1994), Premkumar and Roberts (1999), Beatty et al., (2001), Wu and Sawy (2003), Riemenschneider et al., (2003), Grandon and Pearson (2004), Huy and Filiatrault (2006), Jeon et al., (2006), Chong (2006), Sanayei and Rajabion (2009), Sameni and Khoshalhan (2009) 


\begin{tabular}{|c|c|c|c|}
\hline Context & $\begin{array}{l}\text { Factors, realized } \\
\text { as EC adoption } \\
\text { determinants in } \\
\text { family SMEs, in } \\
\text { the current study }\end{array}$ & $\begin{array}{l}\text { Factors used in the previous related } \\
\text { studies or models }\end{array}$ & Source of studies \\
\hline & & Ease of Use & $\begin{array}{l}\text { Igbaria (1997), Riemenschneider et } \\
\text { al.,(2003), Seyal et al., (2004), Grandon } \\
\text { and Pearson (2004), Lin and Wu } \\
\text { (2004), Wymer and Regan (2005), } \\
\text { Ghamatrasa (2006), Ghorishi (2009), } \\
\text { Abbasi et al.,(2010), HAJIHA, et al., } \\
\text { (2010) }\end{array}$ \\
\hline & & Self-Efficacy & $\begin{array}{l}\text { Compeau and Higgins (1995b), } \\
\text { Venkatesh and Davis (2000), Lee } \\
\text { (2004), Dholakia and Kshetri (2004), } \\
\text { Celuch et al., (2007), Venkatesh and } \\
\text { Bala (2008) }\end{array}$ \\
\hline
\end{tabular}

Effort Expectancy

CEO's Innovativeness/ Innovation Champion

Managers' (CEO) Knowledge of the New Technologies and of E-Commerce

Awareness

Owner(CEO)

(Personality)

Owner-manager's(CEO) Managerial \& IT Experience

(CEO) Interest

Computer Playfulness

(CEO)Network Intension

Past Behavior

Experience

Past Use

Objective Usability

Feedback Effects of Adoption Decision

A.6 Adjustment

Perceived Enjoyment

Outcome Expectations

Performance Expectancy

Perceived Organizational Readiness
Thong (1999), Thong and Yap (1995), Scupola (2003), Lee (2004), Seyal et al., (2004), Al-Qirim (2005), Wymer and Regan (2005), Huy and Filiatrault(2006), Jeon et al.,(2006), Al-Qirim (2007), Afzal (2008), Sanayei and Rajabion (2009), Ghobakhloo et al.,(2011b),Zohoori et al., (2013)

Looi (2005), Huy and Filiatrault (2006), Jeon et al.,(2006), Roberts and Toleman (2007)

Idisemi et al., (2011), Hajli and Bugshan (2012)

Thong (1999), Croteau and Li (2003),

Ching and Ellis (2004), Zhuang and Lederer (2004), Tsao et al., (2004), Sparling et al., (2007)

Dholakia and Kshetri (2004), Sarosa and Underwood (2005),Wymer and Regan (2005), Chuang et al., (2007)

Iddris (2012)

Venkatesh and Bala (2008)

Chong (2008)

Bagozzi et al., (1992)

Venkatesh and Davis (2000)

Kim and Malhotra (2005a,2005b)

Venkatesh and Bala (2008)

Venkatesh and Bala (2008)

Chong (2008)

Venkatesh and Bala (2008)

Iacovou et al., (1995), Mehrtens et al., (2001), Grandon and Pearson (2004),

Molla and Licker (2005),

Sutanonpaiboon and Pearson (2006), Chong (2006), Hajkarimi and Azizi 


\begin{tabular}{ll}
\hline & Factors, realized \\
as EC adoption & \\
determinants in Factors used in the previous related & Source of studies \\
family SMEs, in studies or models \\
the current study
\end{tabular}

(2008), Wang and Ahmed (2009), Ghorishi (2009), Sanayei and Rajabion (2009), Hajli and Bugshan (2012)

Kuan and Chau, 2001, Zhu et al., (2003), Dholakia and Kshetri (2004), Zhu and Kraemer (2005), Huy and

$\begin{array}{llll}\text { Business' } & \begin{array}{l}\text { Organizational } \\ \text { Category }\end{array} & \text { Size \& } \text { Business } \\ \text { Contextual } & & & \\ \text { Characteris Are Not } & \\ \text { Controlled } & \end{array}$

Business Age

Business Type

B. 1

Intergenerational

Successions

Managerial Successions

Perceived Organization Resources

Organizational Slack

Facilitating Condition (Financial Chang and Cheung (2001), Ghamatrasa /Technological)

Business Resources

Financial/Technical/Technological Resources (Cost)

B.2 Perceived Organization Resources

Filiatrault (2006), Jeon et al.,(2006), Chong (2006), Al-Qirim (2007), Sparling et al., (2007), Chuang et al., (2007), Afzal (2008), Sanayei and Rajabion (2009)

Hinson and Abor (2005), Chong (2006), Chuang et al., (2007), Sanayei and Rajabion (2009)

Chuang et al., (2007)

Sartori (2011)

Sartori (2011)

Kurnia and Alzougool (2008), Kurnia et al., (2009)

(2006)

Molla and Licker (2005)

Kuan and Chau (2001), Ling (2001), Mirchandani and Motwani (2001),Chwelos et al., (2001), Mehrtens et al., (2001), Riemenschneider and McKinney (2001-2002), Wu and Sawy (2003), Lertwongsatien and Wongpinunwatana (2003), Zhu et al., (2003), Scupola (2003), Doolin et al., (2003), Grandon and Pearson (2004), Lee (2004), Tsao et al., (2004), Sarosa and Underwood (2005), Huy and Filiatrault (2006), Yeh and Chang (2007), Sameni and Khoshalhan (2009), Iddris (2012)

Human Resources

Employees' Knowledge of (IS)

Molla and Licker (2005)

Thong (1999), Premkumar and Roberts

(1999), Kuan and Chau (2001) Mirchandani and Motwani (2001), Scupola (2003), Zhu et al., (2003), Wu and Sawy (2003), Zhu and Kraemer (2005), Sarosa and Underwood (2005) Huy and Filiatrault (2006), Jeon et al., (2006), Kurnia and Alzougool (2008), Ghobakhloo et al., (2011a), Iddris (2012)

Technological Readiness/E-Business Technology
Srinivasan et al., (2002), Wu and Sawy (2003), Jeon et al., (2006), Sparling et al., (2007), Kurnia and Alzougool 


\begin{tabular}{ll}
\hline & Factors, realized \\
as EC adoption Factors used in the previous related Source of studies \\
determinants in studies or models \\
family SMEs, in \\
the current study
\end{tabular}

Technology Resources

Adoption

Commitment/Financial

Resources/Implementation Cost

Organizational IT Competence

(Organizational) Awareness

EC (Organizational)

(limitations)

Lack of Skills and Training

SME's Prior Experience

Information Sources

Managerial Time

Lack of Managerial Time

Perceived Governance

(Organizational) Governance

Communication Channels

Communication Amount

Having Clearly Defined Roles

B.3 Perceived

Governance

B.4 Perceived
Organizational
Support

Top Management (CEO) Support Managing Change Issues Framework

Organizational Centralization

Organizational Formalization

Organizational Interconnectedness

Organizational Complexity

Organizational system openness the Organization)

\section{(2008)}

Molla and Licker (2005)

Zhu et al., (2003), Scupola (2003), Wymer and Regan (2005), Zhu and Kraemer (2005), Kaynak et al., (2005), Sarosa and Underwood (2005), Jeon et al., (2006), Al-Qirim (2007), Kurnia and Alzougool (2008), Afzal, 2008, Sanayei and Rajabion (2009), Idisemi et al., (2011), Iddris (2012)

Ifnedo (2011)

Molla and Licker (2005) barriers

Scupola (2003), Kaynak et al. (2005)

Idisemi et al., (2011)

Wymer and Regan (2005)

Chong (2006)

Mirchandani and Motwani(2001)

Chong (2010)

Alzougool and Kurnia (2008), Kurnia et al., (2009)

Molla and Licker (2005), Meftah et al., (2015)

Chong (2006), Sanayei and Rajabion (2009)

Chong (2006), Sanayei and Rajabion (2009), Nogoev et al., (2011)n

Alzougool and Kurnia (2008)

Seyal et al., (2004)

Idisemi et al., (2011)

Having Systematic Process for

Lack of Policy and Institutional

Alzougool and Kurnia (2008)

Idisemi et al., (2011)

Organizational Support (Support within

Lertwongsatien and Wongpinunwatana (2003), Wu, Mahajan, and Balasubramanian (2003), Zhuang and Lederer (2004), Grandon and Pearson (2004), Tsao et al., (2004), Sparling et al., (2007), Ghorishi (2009)

Mirchandani and Motwani (2001), Tsao et al., (2004), Seyal et al., (2004), Sanayei and Rajabion (2009), Ifnedo (2011), Ghobakhloo et al., (2011a) 


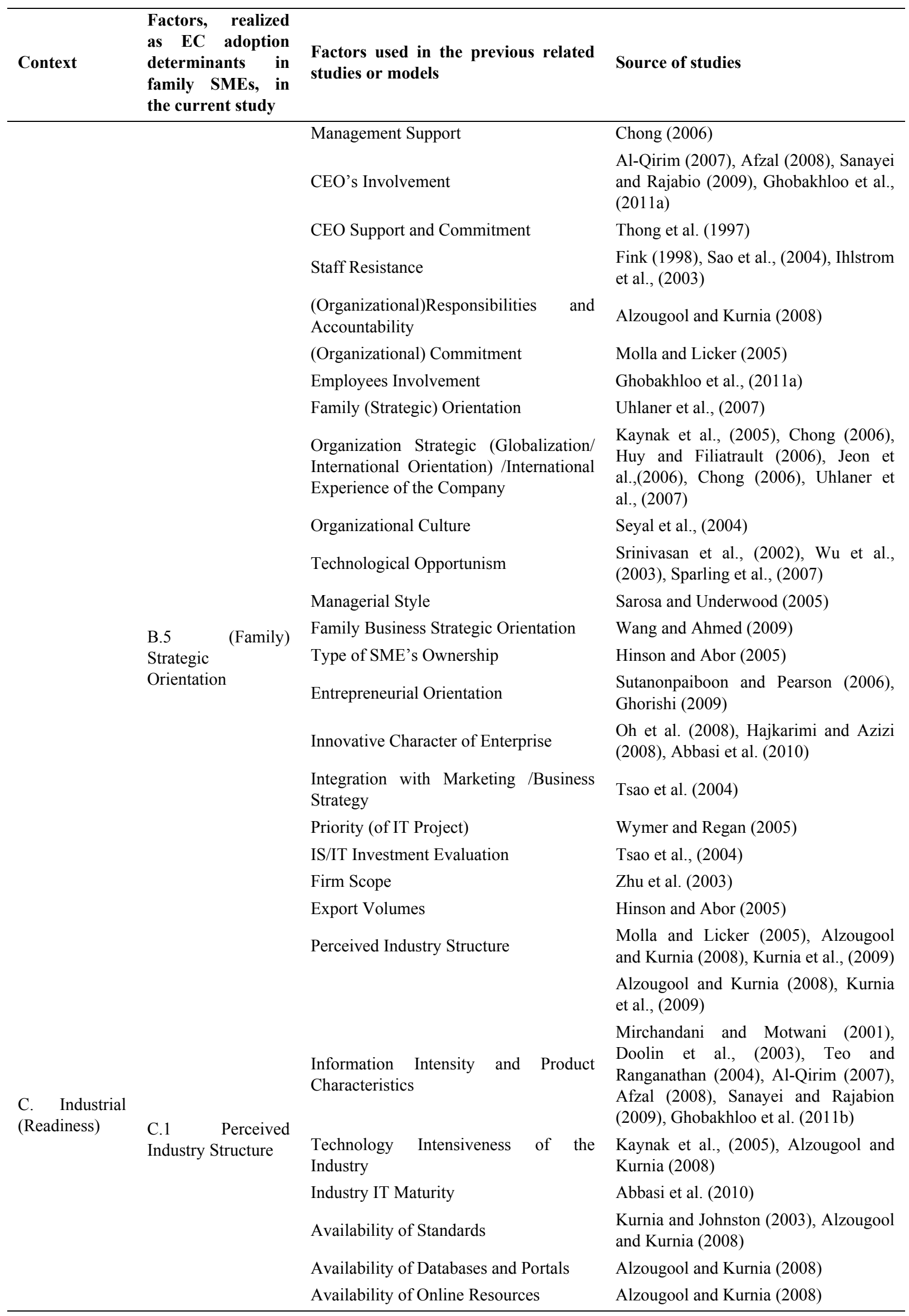




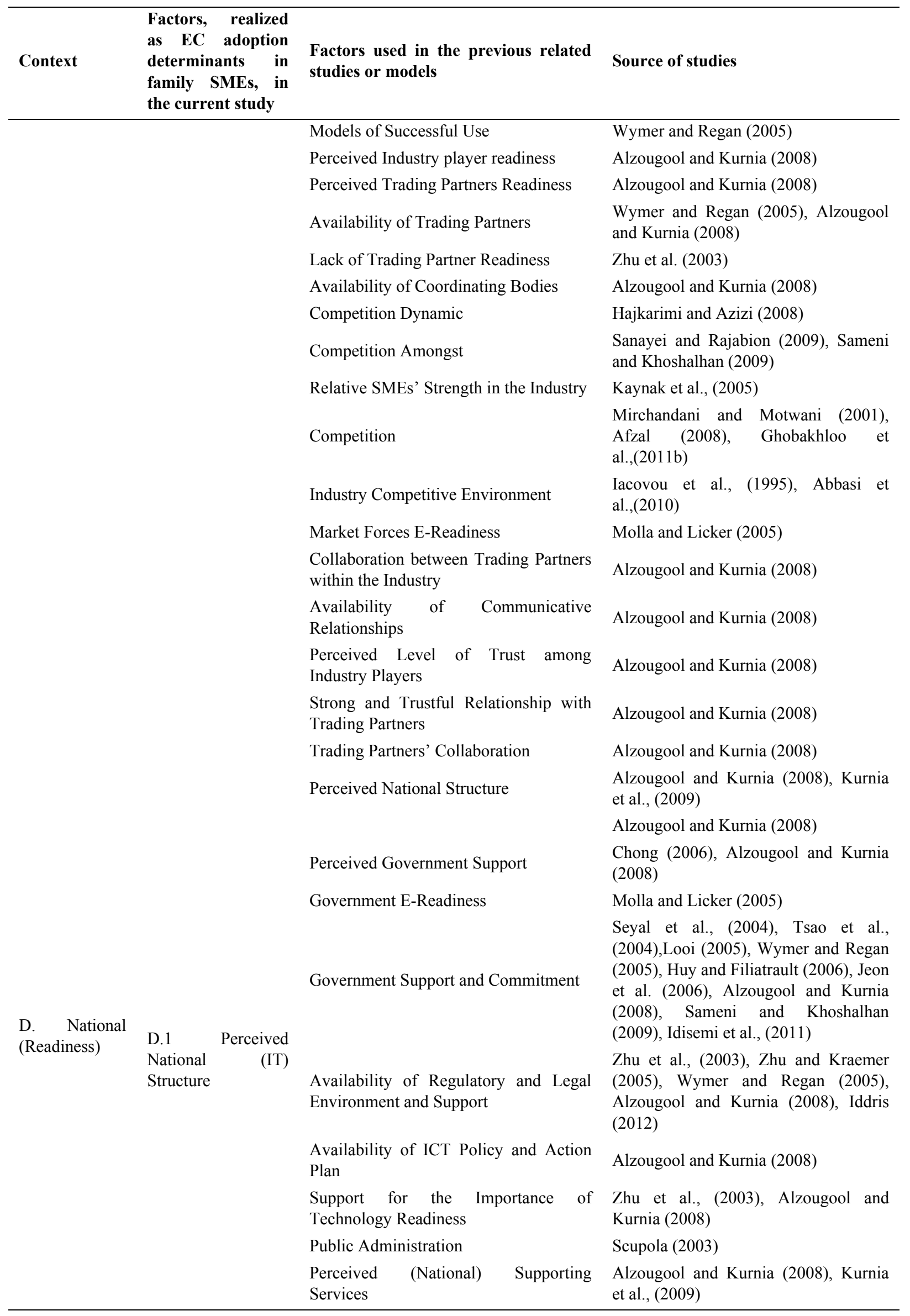


Factors, realized

as EC adoption

Context determinants in

family SMEs, in

the current study
Factors used in the previous related

studies or models

Source of studies
Availability of Support from

Technology Vendors

Availability of EC-Related

Technologies

Technology Providers

Availability and Support of Skilled Labor

Availability of Financial Support

Availability of Affordable Consultancy

Supports (Informational Institutions)

External Assistance

Technology Consultants

External Expertise and Services Availability and Support

Consultant Effectiveness and

Competence

Availability of National Infrastructure

Environment

Relevant Environmental Participation

Non-Trading Institutional Influence

Availability of Logistics and Transport Infrastructure

Availability of Telecommunication Infrastructure

Availability of Capable Technology and

Telecommunication Infrastructure

ICT Infrastructure

Culture and Religion (Public/Customer)

Consumer Readiness

People Resistance \& Culture

Ease of Use for Customer

Usefulness for Customers

Public Awareness

Public Purchasing Behavior

Public Shopping Trend
Cragg and King (1993), Fink (1998), Doolin et al., (2003), Wymer and Regan (2005), Sarosa and Underwood (2005), Al-Qirim (2007) Alzougool and Kurnia (2008), Sanayei and Rajabion(2009), Ifnedo (2011), Ghobakhloo et al.,(2011b)

Scupola (2003), Wymer and Regan (2005), Sarosa and Underwood (2005), Alzougool and Kurnia (2008), Sameni and Khoshalhan (2009)

Sameni and Khoshalhan (2009)

Alzougool and Kurnia (2008)

Ifnedo (2011)

Cohen and Kallirroi (2006)

Ghobakhloo et al.,(2011a)

Sameni and Khoshalhan (2009)

Thong et al. (1997)

Thong et al. (1997)

Sarosa and Underwood (2005), Huy and Filiatrault (2006), Alzougool and Kurnia (2008)

Sutanonpaiboon and Pearson (2006)

Chong (2006)

Chong (2006)

Alzougool and Kurnia (2008)

Idisemi et al., (2011)

Alzougool and Kurnia (2008)

Sanayei and Rajabion (2009)

Sanayei and Rajabion (2009)

Sanayei and Rajabion (2009)

Afzal (2008), Iddris (2012)

Sutanonpaiboon and Pearson (2006)

Sutanonpaiboon and Pearson (2006)

Afzal (2008), Sameni and Khoshalhan (2009)

Afzal (2008), Sameni and Khoshalhan (2009)

Sameni and Khoshalhan (2009) 


\begin{tabular}{llll}
\hline & $\begin{array}{l}\text { Factors, realized } \\
\text { as EC adoption } \\
\text { determinants in } \\
\text { family SMEs, in } \\
\text { the current study }\end{array}$ & $\begin{array}{l}\text { Factors used in the previous related } \\
\text { studies or models }\end{array}$ & Source of studies \\
& & $\begin{array}{l}\text { Perceived Availability of Electronic } \\
\text { Banking System (EC-Adopted Banking Afzal (2008) } \\
\text { System) } \\
\text { Reliable Banking System }\end{array}$ \\
\hline & & Sameni and Khoshalhan (2009) \\
\hline
\end{tabular}

Table A2. Definitions of selected first order factors in the current study

\begin{tabular}{|c|c|}
\hline Factor & Definition \\
\hline EC Adoption & $\begin{array}{l}\text { Degree to which the communication, interaction and transaction functions are } \\
\text { electronically conveyed in a wider and more diversified range of external } \\
\text { 'business-linked' and/or 'customer-linked' business relationships, over ICT } \\
\text { technological structure' (extracted from Chong, 2006; Chong, 2008) }\end{array}$ \\
\hline Perceived Need & $\begin{array}{l}\text { CEO's perception of inner motives direct to balancing inner actual states and desired } \\
\text { states (extracted from Hersey \& Blanchard, 1993; Boone \& Kurtz, 2011) }\end{array}$ \\
\hline $\begin{array}{l}\text { Perceived Usefulness } \\
\text { (Awards) }\end{array}$ & $\begin{array}{l}\text { The extent to which a CEO believes that the application of a special system make } \\
\text { her/him able to do the task better (Davis, 1989) }\end{array}$ \\
\hline $\begin{array}{l}\text { Perceived } \\
\text { Disadvantages }\end{array}$ & $\begin{array}{l}\text { CEO's perception of to what extent they have incurred a loss by using any online } \\
\text { service (extracted from Lim, 2003) }\end{array}$ \\
\hline Subjective Norm & $\begin{array}{l}\text { CEO's perception that most people who are important to him/her think he/she should or } \\
\text { should not perform the behavior in question (adopted from Fishbein \& Ajzen, 1975) }\end{array}$ \\
\hline Anchor & $\begin{array}{l}\text { CEO's first personal estimation of results' desirability (extracted from Tvershy \& } \\
\text { Kahneman, 1974; Hersey \& Blanchard, 1993; Venkatesh \& Bala, 2008) }\end{array}$ \\
\hline Adjustment & $\begin{array}{l}\text { Performance-based CEO's adjustment in mental evaluation of satisfaction (extracted } \\
\text { from Tvershy \& Kahneman, 1974; Hersey \& Blanchard, 1993; Venkatesh \& Bala, } \\
\text { 2008) }\end{array}$ \\
\hline $\begin{array}{l}\text { Intergenerational } \\
\text { Successions }\end{array}$ & Changing the family in charge over generation. (extracted from Molly, 2009) \\
\hline $\begin{array}{l}\text { Perceived } \\
\text { Organizational } \\
\text { Resources }\end{array}$ & $\begin{array}{l}\text { CEO's perception of availability of human, financial, and technological resources of a } \\
\text { firm (adopted from Tan et al., 2007) }\end{array}$ \\
\hline $\begin{array}{l}\text { Perceived } \\
\text { Organizational } \\
\text { Governance }\end{array}$ & $\begin{array}{l}\text { CEO's perception of the strategies, tactical, and operational models designing the } \\
\text { organization's structure to establish objectives, allocate resources, and make decisions } \\
\text { (adopted from Tan et al., 2007) }\end{array}$ \\
\hline $\begin{array}{l}\text { Perceived } \\
\text { Organizational } \\
\text { Support }\end{array}$ & $\begin{array}{l}\text { CEO's perception of availability of support within the organization (extracted from } \\
\text { Grandon \& Pearson, 2004) }\end{array}$ \\
\hline $\begin{array}{l}\text { Perceived } \\
\text { Structure }\end{array}$ & $\begin{array}{l}\text { CEO's perception of nature structure of an industry (adopted from Kurnia \& Johnston, } \\
\text { 2003; Kurnia \& Alzougool, 2008; Kurnia et al., 2009) }\end{array}$ \\
\hline $\begin{array}{l}\text { Family (Strategic) } \\
\text { Orientation }\end{array}$ & $\begin{array}{l}\text { The extent to which the organizational mission is subjected to family oriented goals } \\
\text { (extracted from Uhlaner et al., 2007; Wang \& Ahmad, 2009; Molly, 2009) }\end{array}$ \\
\hline
\end{tabular}

\section{Copyrights}

Copyright for this article is retained by the author(s), with first publication rights granted to the journal.

This is an open-access article distributed under the terms and conditions of the Creative Commons Attribution license (http://creativecommons.org/licenses/by/3.0/). 